\title{
THE IMPACT OF CASH CONVERSION CYCLE EFFIENCY ON OPTIMIZATION OF RETURN ON ASSET ON PROPERTY \& REAL ESTATE SUBSECTORS
}

\author{
Tika Al Shafti ${ }^{1)}$ and Afriyanti Hasanah ${ }^{2 *}$ \\ Managerial Accounting Study Program \\ Politeknik Negeri Batam \\ Email: shaftialtika@gmail.com ${ }^{1)}$, afriyanti@polibatam.ac.id ${ }^{2)}$
}

\begin{abstract}
This study aims to examine the impact of cash conversion cycle efficiency on optimization of return on assets on property \& real estate sub-sector listed in Indonesia Stock Exchange (IDX) period 20132016. The cash conversion cycle is proxied by 3 variables: average inventory period, average collection period and average payment period. Sampling method using purposive sampling technique. The data used is cross section data. Data analysis techniques use simple linear regression analysis. The result of research stated that debt repayment period has positive effect to return on asset of company. Cash conversion cycle, inventory turnover period and receivable collection period have no effect on return on asset of the company.
\end{abstract}

Keywords: cash conversion cycle, average inventory period, average collection period, average payment period, return on asset.

\begin{abstract}
ABSTRAK
Penelitian ini bertujuan untuk menguji dampak efisiensi siklus konversi kas terhadap pengoptimalan return on asset subsektor property \& real estate yang terdaftar di Bursa Efek Indonesia (BEI) periode 2013-2016. Siklus konversi kas diproksikan dengan 3 variabel yaitu periode perputaran persediaan, periode pengumpulan piutang dan periode pembayaran utang. Metode pengambilan sampel menggunakan teknik purposive sampling. Data yang digunakan adalah data cross section. Teknik analisis data menggunakan analisis regresi linier sederhana. Hasil penelitian menyatakan periode pembayaran utang berpengaruh positif terhadap return on asset perusahaan. Siklus konversi kas, periode perputaran persediaan dan periode pengumpulan piutang tidak berpengaruh terhadap return on asset perusahaan.
\end{abstract}

Kata kunci: siklus konversi kas, periode perputaran persediaan, periode pengumpulan piutang, periode pembayaran utang, return on asset. 


\section{INTRODUCTION}

Since begin the era of the ASEAN Economic Community (AEC) in 2015, several industrial sectors have begun to prepare. The Central Statistics Agency (BPS) reported that Indonesia's gross domestic product (GDP) or economic growth in 2017 reached 5.07\%. This figure, according to BPS, is the highest rate of economic growth since 2014. The source of Indonesia's economic growth in 2017 was the processing industry by $0.91 \%$, followed by the construction sector by $0.67 \%$, the trade sector by $0.59 \%$ and the agricultural sector by $0.49 \%$. The property and real estate sector is one of the most important sectors in a country. Economic growth in Indonesia is supported by the property and real estate sectors.

To maintain the survival of the company in the face of intense competition, it is necessary to properly manage and management. Companies not only focus their goals on maximizing profits, but also by how they can manage existing working capital. The existence of proper working capital management, aims to support the company to be more effective and efficient to improve the company's performance and achieve the expected success.

The most important business activities for the continuity of the company's operations are maintaining the availability of working capital and the cash conversion cycle in order to remain profitable to maintain sustainable production. The cash conversion cycle is the period of time the company needs from the time the purchased raw material is paid, until the accounts receivable from the sale of goods can be collected. The cash conversion cycle is an important tool in estimating how well the company performs in managing its working capital (Keown, 2010).

The researcher aims to replicate the research conducted by Yazdanfar \& Ohman (2014). The research objective is to see how the efficient management of cash conversion cycles to profitability manage resources carried out by

optimization in the property \& real estate sector companies. The proxy of the cash conversion cycle in this study, namely the inventory turnover period, the collection period of accounts receivable and the period of debt repayment. Profitability is proxied using return on assets (ROA).

The difference between Yazdanfar \& Ohman's research with the author is the type of proxy for the size of the company and the sample used. The size of the company as a control variable in Yazdanfar \& Ohman (2014) research is proxied using the natural logarithm of total sales while, in this study will use the natural logarithm of total assets. The research sample used by Yazdanfar \& Ohman (2014) is in the small and medium business sector in Sweden, for this study a sample used by the property \& real estate sector companies.

\section{Problem Case}

Based on the background described, then the formulation of the problem in this study is how the efficiency of the cash conversion cycle impacts on the optimization of return on assets of the property and real estate sectors.

\section{THEORETICAL BASIS \\ Signaling Theory}

This theory was put forward by Ross (1977), relating to the availability of information held by corporate executives in the form of better information and tends to convey the information to prospective investors. Ross (1977) developed a model in which capital structure (the use of debt) is a signal conveyed by managers to the market. The manager will provide a more reliable signal using a debt indicator.

\section{Agency Theory}

This agency theory explains the
relationship between company
management as an agent with capital
owners or company owners as principal.
This theory was first put forward by Jensen
$\&$ Meckling (1976), in the agency
relationship there is a contract in which the


principal assigns the agent to do some work related to his interests and authorizes the agent to make the best decision for the principal.

\section{Stakeholder Theory}

This theory was first put forward by Freeman (1984) in his book entitled Strategic Management: A Stakeholder Approach, this theory arises because of the development of awareness and understanding that the company has stakeholders, namely parties with an interest in the company. The company is not an entity that only operates for its own sake, but must provide benefits to stakeholders (shareholders, creditors, consumers, suppliers, governments, communities, analysts and other interested parties). All stakeholders have the right to obtain information about company activities that can influence their decision making.

\section{RESEARCH METHOD Research methods \\ Types and sources of data}

This research is a quantitative research where the data used is secondary data with the cross section method. The data measurement scale used in this study is ratio scale. Sources of data used are financial statements of companies listed on the Indonesia Stock Exchange for the 2013-2016 period.

\section{Independent Variable \\ Cash Conversion Cycle (CCC)}

The cash conversion cycle is the sum of the period of supply or Average Age of the Inventory (AAI) and the collection period of the receivables or Average Collection Period (ACP) minus the debt payment period or the Average Payment Period (APP). The cash conversion cycle is calculated using a ratio scale. Mathematically written as follows:
$\mathrm{CCC}=\mathrm{AAI}+\mathrm{ACP}-\mathrm{APP}$

$\&$ Zutter, 2010)

Components in the cash conversion cycle:

1. Average Age of the Inventory (AAI)

Inventory turnover period is the period of time needed to sell existing merchandise (inventory) in a warehouse to consumers. The following formula is used to calculate the length of the supply period:

AAI $=\frac{\text { Inventories }}{\text { Cost of good sold }} \quad$ X 365 days

Source: (Gitman \& Zutter, 2010)

\section{Average Collection Period (ACP)}

The receivable collection period is the average time period needed to convert receivables to cash. The following formula is used to calculate the receivable collection period:

$\mathrm{ACP}=$ days

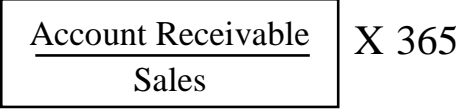

Source: (Gitman \& Zutter, 2010)

\section{Average Payment Period (APP)}

The debt payment period is the period of time needed from the purchase of merchandise to the payment to the supplier. The following formula is used to calculate the debt payment period:

$\mathrm{APP}=$

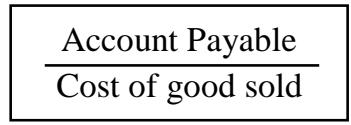

X 365

hari

Source: (Gitman \& Zutter, 2010)

\section{Dependent Variables \\ Return on Assets (ROA)}

In this study profitability is measured using an approach related to the use of assets, namely the return of total assets or better known as Return on Assets (ROA). Return on assets which is a ratio scale in the form of percentages, is calculated by comparing net income with total assets of the company (Keown, Martin, Petty, \& JR, 2008). The greater the value of ROA, the better the company's performance, because 
the return on investment is greater. Mathematically written as follows:

ROA $=\frac{\text { Net income }}{\text { Total asset }}$

Source: (Keown, Martin, Petty, \& JR, 2008)

\section{Control Variables \\ Firm Size}

Firm Size (Firm Size) is an indicator that can show the condition or characteristics of a company. The size of the company is classified into large and small. The proxy of the size of the company in this study uses total assets:

Firm Size $=$ LN of Total Assets

Source: (Isik, 2017)

\section{Firm Age}

The age of the company is used to measure the influence of the length of time the company operates. By knowing the age of the company, it will be known also the extent to which the company can survive. In this study the age of the company was seen since the company was operational until 2016. Mathematically the age of the company can be calculated as follows:

Firm Age $=$ LN of Age $\left(\mathrm{YEAR}_{\mathrm{n}}-\mathrm{YEAR}_{\mathrm{t}}\right)$

Source: (Isik, 2017)

Information:

YEAR $_{\mathrm{t}}$ : the first year the company operates $\mathrm{YEAR}_{\mathrm{n}}$ : up to the year of research taken

\section{Sampling Technique}

The sample on this study was determined non-probability or non-random by using purposive sampling method with criteria, first listed on the Indonesia Stock Exchange (IDX) as property \& real estate subsector issuers that publish their financial statements during the 2013-2016 research period. Second, the required data is complete and publishes financial reports that have been audited by independent auditors during the 2013-2016 period.
Third, the company's financial statements are presented in rupiah.

\section{Data Collection Technique}

Data collection techniques in this study use archive techniques in the database. Financial report data in the form of balance sheet and income statement are collected then the data is selected according to the criteria that have been determined. The data used in this study is cross section data.

\section{Data Processing Techniques}

The data processing used in this study was to use the Statistical Product and Service Solution (SPSS) program version 17. This study used four steps in managing the data obtained from the respondents.

\section{Data Analysis Technique Descriptive Statistical Analysis}

According to Ghozali (2012) the variables used in this study are described using descriptive statistics to determine the mean, minimum, maximum and standard deviation values.

\section{Classic assumption test}

\section{Normality Test}

Normality test aims to test whether the regression model, confounding variables or residuals have a normal distribution. Data that is feasible to be used in a study is normal data. Data normality can be seen using the Kolmogorov-Smirnov normal test. The decision criteria are if sig $>0.05$ then the data is normally distributed and if sig $<0.05$ then the data is not normally distributed (Ghozali, 2012).

\section{Heteroscedasticity test}

Heteroscedasticity test aims to test whether in the regression model there is a residual variance inequality one observation to another observation (Ghozali, 2012). A good regression model is homoskedasticity or heteroscedasticity does not occur. Significant value of correlation $>0.05(\alpha=5 \%)$ it can be 
concluded that heteroscedasticity does not occur.

\section{Multicollinearity Test}

This test aims to test whether the regression model found correlation between independent variables. A good regression model should not have correlation between independent variables. The value that is generally used to indicate the presence of multicollinearity is tolerance value $<0.1$ or VIF $>10$ (Ghozali, 2012).

\section{Simple Linear Regression Analysis Test}

The form of regression test equations in this study are as follows:

$\mathrm{ROA}_{\mathrm{i}}=\alpha+\beta_{1} \mathrm{CCC}_{\mathrm{i}}+\beta_{2}$ Size $_{\mathrm{i}}+\beta_{3}$ Age $_{\mathrm{i}}+\varepsilon_{\mathrm{i}}$ (H1)

$\mathrm{ROA}_{\mathrm{i}}=\alpha+\beta_{1} \mathrm{AAI}_{\mathrm{i}}+\beta_{2}$ Size $_{\mathrm{i}}+\beta_{3} \mathrm{Age}_{\mathrm{i}}+\varepsilon_{\mathrm{i}}$ (H2)

$\mathrm{ROA}_{\mathrm{i}}=\alpha+\beta_{1} \mathrm{ACP}_{\mathrm{i}}+\beta_{2}$ Size $_{\mathrm{i}}+\beta_{3} \mathrm{Age}_{\mathrm{i}}+\varepsilon_{\mathrm{i}}$ (H3)

$\mathrm{ROA}_{\mathrm{i}}=\alpha+\beta_{1} \mathrm{APP}_{\mathrm{i}}+\beta_{2}$ Size $_{\mathrm{i}}+\beta_{3}$ Age $_{\mathrm{i}}+\varepsilon_{\mathrm{i}}$ (H4)

Information:

$$
\begin{array}{ll}
\text { ROA } & =\text { Return on Assets } \\
\mathrm{i} & =\mathrm{i}-\text { th entity } \\
\alpha & =\text { Constant value } \\
\beta_{1}-\beta_{3} & =\text { Regression coefficient (value } \\
& \quad \text { increase or decrease) } \\
\text { CCC } & =\text { Cash conversion cycle } \\
\text { AAI } & =\text { Period of supply } \\
\text { ACP } & =\text { Receivable collection period } \\
\text { AAP } & =\text { Debt payment period } \\
\text { Size } & =\text { company size } \\
\text { Age } & =\text { company age } \\
\varepsilon & =\text { Error }
\end{array}
$$

\section{R-Square Test $\left(\mathbf{R}^{\mathbf{2}}\right)$}

The test of the coefficient of determination essentially measures how far the ability of the model in explaining the variation of the dependent variable. The coefficient of determination is between zero or one. A small $\mathrm{R}^{2}$ value means that the ability of the dependent variables is very limited. A value close to one means that the independent variables provide almost all the information needed to predict the variation of the dependent variable (Ghozali, 2012). How to determine the coefficient of determination by looking at the adjusted R2 column, where the value of $\mathrm{R}^{2}>0.05$ shows high accuracy.

\section{Simultaneous Test (Statistical F Test)}

The $\mathrm{F}$ test is used to determine the significance of the effect of inventory turnover period, collection period of accounts receivable, debt repayment period (cash conversion cycle) simultaneously / jointly on return on assets (Ghozali, 2012). With the F-test criteria if the significance value $<0.05(\alpha=5 \%)$ means that the independent variables simultaneously affect the dependent variable.

\section{Partial Test (Statistical Test-t)}

Partial test (statistical t-test) aims to determine the significance of the role partially (individually) between the independent variable and the dependent variable by assuming that other independent variables are considered constant. Ghozali (2012) states that if the significance value $<0.05(\alpha=5 \%)$ means that there is a significant influence between variables partially with the dependent variable.

\section{Hypothesis}

Different research results were obtained in previous studies. The results of Margaretha \& Oktaviani's (2016) study say that the cash conversion cycle has a negative effect on profitability measured using ROA. Research conducted by Muscettola (2014) shows that the average receivable period has a significant positive relationship with profitability, this shows that not always the low cash conversion cycle will increase profitability. In short, all previous research shows that working capital management has an effect on the company's profitability. The cash conversion cycle in this study was tested with the hypothesis:

H1: Cash conversion cycle affects the company's ROA. 
Inventory turnover period is the period of time needed to turn inventory into sales. Good inventory management is by accelerating inventory turnover. Research conducted by (Sharma \& Kumar, 2011) concludes the inventory turnover period has a negative effect on the profitability of the company. This means that the shorter or faster the inventory conversion cycle, the more the company's ROA increases. The inventory turnover period in this study was tested with the hypothesis:

$\mathrm{H} 2$ : Average age of inventory has a negative effect on the company's ROA.

The collection period for receivables is the period of payment of receivables from buyers. The results of research conducted by Anser \& Malik (2013) concluded that the collection period of accounts receivable negatively affects the profitability of the company. This means that the shorter the time needed to convert receivables to cash, the more ROA will increase. The collection period for receivables in this study was tested with the hypothesis:

H3: Average collection period has a negative effect on the company's ROA.

The debt payment period is the period of time needed to pay the obligation to the supplier. If payment of trade debt is extended, then additional capital owned can be used to make investments. Positive influence means that the longer a company pays debt, the more ROA the company increases (Anser \& Malik, 2013). The debt payment period in this study was tested with the hypothesis:

H4: Average payment period has a positive effect on the company's ROA.

Based on previous explanations, the research model can be described as follows:
Picture 1 Research Model

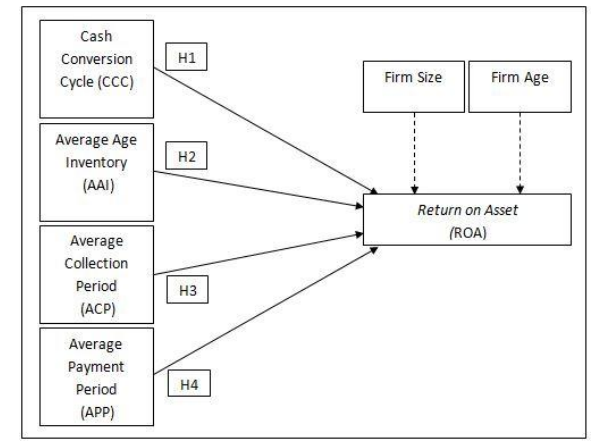

Source: Submission of the research hypothesis

\section{RESULT AND DISCUSSION Descriptive Statistics}

The minimum value or the lowest period of inventory is 1.6957 (AAI $=2$ days), which is Roda Vivatex Tbk (RDTX) in 2015. The low period of inventory turnover shows that the company is able to shorten the time needed to sell inventory items in the warehouse. The shorter the time it takes for a company to sell inventory, the faster the company will earn revenue from the inventory it has sold.

\section{Table 1 Descriptive Statistics}

\begin{tabular}{lcrrrr}
\hline Variabel & N & Minimum & \multicolumn{1}{c}{ Maximum } & \multicolumn{1}{c}{ Mean } & \multicolumn{1}{c}{$\begin{array}{c}\text { Std. } \\
\text { Deviation }\end{array}$} \\
\hline AAl & 159 & 1.6957 & 4369.0649 & 734.5632 & 685.4662 \\
ACP & 159 & 0.3310 & 261.0850 & 47.9857 & 52.0940 \\
APP & 159 & 2.8021 & 283.8934 & 58.1870 & 52.4535 \\
CCC & 159 & -24.5078 & 4357.0234 & 724.3619 & 681.8802 \\
ROA & 159 & -0.0880 & 0.2541 & 0.0579 & 0.0571 \\
SIZE & 159 & 25.7727 & 31.4510 & 28.9627 & 1.3006 \\
AGE & 159 & 1.0986 & 3.8501 & 3.0193 & 0.5722 \\
\hline
\end{tabular}

Source: Data processed with SPSS 17

The value of the maximum or the highest period of inventory is 4369.0649 $(\mathrm{AAI}=4,369$ days $/ \pm 12$ years $)$ namely Bekasi Asri Beginner Tbk (BAPA) in 2016. The high period of inventory turnover shows that companies need a long period of time to sell supplies to consumers. The longer the time it takes for a company to sell inventory, then the company will also get a long time from the inventory sold.

The average (mean) value of the property $\&$ real estate sector supply period is 734.5632 ( $\mathrm{AAI}=735$ days) which means that the average company takes 735 days to convert inventory into sold goods to 
consumers and standard deviation values or show flat inequality AAI is 685.4662 .

\section{Classic Assumption Test Normality Test}

Based on table 2 below it can be seen that the significance value is more than 0.05 , so it can be concluded that the regression model of the hypothesis is normally distributed and suitable for use in research.

\begin{tabular}{lcc}
\multicolumn{1}{c}{ Table 2} & Normality & Test Result \\
\hline \multicolumn{1}{c}{ Normality Test } & $\begin{array}{c}\text { Unstandardized } \\
\text { Residual }\end{array}$ & Information \\
\hline Kolmogorov-Smirnov Z & 1.065 & Data are normally distributed \\
Asymp. Sig. (2-tailed) & 0.207 & \\
\hline
\end{tabular}

Source: Data processed with SPSS 17

\section{Heteroscedasticity Test}

Based on table 3 below it can be seen that the significance value of each independent variable shows a value of more than 0.05 so that it can be concluded that in testing the regression model there is no heteroscedasticity.

\section{Table 3 Heteroscedasticity Test Result}

\begin{tabular}{|c|c|c|}
\hline Independent Variable & Significance & Information \\
\hline Inventory Period & 0.087 & $\begin{array}{c}\text { There is no } \\
\text { heteroscedasticity }\end{array}$ \\
\hline Receivable Period & 0.639 & $\begin{array}{c}\text { There is no } \\
\text { heteroscedasticity }\end{array}$ \\
\hline Payable Period & 0.766 & $\begin{array}{c}\text { There is no } \\
\text { heteroscedasticity }\end{array}$ \\
\hline
\end{tabular}

Source: Data processed with SPSS 17

\section{Multicollinearity Test}

Based on table 4 below it can be seen that each variable has a tolerance value of more than 0.1 and VIF value is smaller than 10. It can be concluded that there is no multicollinearity between independent variables in the regression model.

\section{Table 4 Multicollinearity Test Result}

\begin{tabular}{lcc}
\multicolumn{1}{c}{ Independent Variable } & Tolerance & VIF \\
\hline Inventory Period & 0.928 & 1.078 \\
Receivable Period & 0.831 & 1.204 \\
Payable Period & 0.791 & 1.265 \\
\hline
\end{tabular}

Source: Data processed with SPSS 17

\section{Simultaneous Hypothesis Test Results}

Simultaneous testing results between variable inventory turnover period, collection period of accounts receivable and period of debt repayment on return on assets can be seen in table 5:
Table 5 Statistics F Test Results

\begin{tabular}{lccc}
\hline Independent Variable & F & Sig. & $\begin{array}{c}\text { Adjusted } \mathbf{R} \\
\text { Square }\end{array}$ \\
\hline $\begin{array}{l}\text { Inventory Period } \\
\text { Receivable Period } \\
\text { Payable Period }\end{array}$ & 7.053 & 0.000 & 0.103 \\
\hline
\end{tabular}

Source: Data processed with SPSS 17

Based on Table 5 above it can be seen that the $\mathrm{F}$ test results obtained Fcount value of 7.053 with a significance value of 0.000 $<0.05$ meaning that simultaneously / simultaneously the independent variables have a significant effect on the dependent variable. The value of the coefficient of determination on the adjusted $\mathrm{R}$ square column is obtained at 0.103 , which means that this study shows $10.3 \%$ of return on assets is explained by the variable inventory turnover period, collection period of accounts receivable and period of debt repayment.

\section{Data analysis}

The following is a summary table of the results of the four research hypothesis tests on property \& real estate sector companies listed on the Indonesia Stock Exchange in the 2013-2016 period, which can be seen in table 6 :

\section{Table 6 Summary of Test Results}

\begin{tabular}{cccc}
\hline \multicolumn{1}{c}{ Hypothesis } & Sig. & Conclusion \\
\hline H1 & Cashconversion cycle affect the company's ROA & 0,352 & $\begin{array}{c}\text { Not } \\
\text { supported }\end{array}$ \\
\hline H2 2 & $\begin{array}{l}\text { Average age of inventory has a negative effect } \\
\text { on the company's ROA }\end{array}$ & 0,309 & $\begin{array}{c}\text { Not } \\
\text { supported }\end{array}$ \\
\hline H3 & $\begin{array}{l}\text { Average collection period has a negative effect } \\
\text { on the company's ROA }\end{array}$ & $0,004^{* * *}$ & $\begin{array}{c}\text { Not } \\
\text { supported }\end{array}$ \\
\hline H4 & $\begin{array}{l}\text { Average payment period has a positive effect } \\
\text { on the company's ROA }\end{array}$ & $0,000^{* *}$ & supported \\
\hline & ** Significance at the level $5 \%(0,05)$ \\
\hline
\end{tabular}

Source: Data is processed from the results of partial tests

\section{Cash Conversion Cycle (CCC) Does Not Affect Company ROA}

Based on the results of hypothesis testing, there is no effect between the cash conversion cycle (CCC) on the company's ROA. These results indicate that if there is an increase or decrease in the period of the cash conversion cycle, it will not affect the level of return on assets of the company. This is because the cash and inventory owned by the company is available and the 
company has anticipated market demand. In addition, the company also uses external funds such as bank loans or from the capital market to fund its operational activities.

The results of this study support the research of Nur, Indrawati, \& Ratnawati (2016) stating that there is no influence between the cash conversion cycle and the profitability of the company. There are differences in the results of this study with the research of Margaretha \& Oktaviani (2016), stating that there is a negative relationship between the cash conversion cycle and the company's profitability.

\section{Average Age of Inventory (AAI) Does Not Affect Company ROA}

The results of the hypothesis research, there is no effect between the preparation average age of inventory (AAI) on the company's ROA. These results indicate that the longer or higher the conversion period, it will not significantly affect the value of return on assets of the company. This is due to the characteristics of property \& real estate companies requiring a long time in the production process. Starting from raw materials, semi-finished goods and finished goods ready for sale. The company has provided appropriate services. Market demand. In addition, the preparations available are durable and not easily damaged or rotten which is not long or short will not affect the profitability of the company.

The results of this study support the research (Gill, Biger, \& Mathur, 2010), stating that there is no relationship between the long period of preparation and the profitability of the company. The results of this study by Anser \& Malik (2013), state that there is a negative relationship between the average age of inventory and the profitability of the company.
Average Collection Period (ACP) Is Not Negatively Influenced Against Company ROA

Based on the results of testing the hypothesis of the significance value, there is an influence between the average collection period (ACP) on the company's ROA. The positive coefficient results indicate the longer the period of collection of receivables, the return on assets will increase. Not always a low collection period of accounts receivable will result in high profitability. Long receivable collection periods can also increase profitability. Demonstrate that sales credit can be used as a strategic tool to increase profitability (Muscettola, 2014). This is because the company experiences an increase in sales and is followed by cash received by the company so that the company invests its funds into receivables (Abuzayed, 2012).

The results of this study support the research of Muscettola (2014), stating that there is a positive relationship between the collection period of accounts receivable and the profitability of the company. The results of this study are not in accordance with the results of research by Alvinasab \& Esmail Davoudi (2013), stating that there is a negative relationship between the collection period of accounts receivable and the profitability of the company.

\section{Average Payment Period (APP) Has a Positive Effect on Company ROA}

Based on the results of testing the hypothesis, there is a significant effect between the average payment period (APP) on the company's ROA. The positive coefficient results indicate the longer the debt repayment period, the return on assets will increase. If the company has a long period of time to pay off the debt, then the additional capital held can be used for the company's working capital needs so that it can increase the ability to generate profits. Companies are more profitable by waiting longer to pay bills by utilizing the credit period provided by the supplier and 
maintaining creditor trust in the company so as not to damage the existing business relationship.

The results of this study support the research of Ponsian, Chrispina, Tago, \& Mkiibi (2014), stating that there is a positive relationship between the period of debt repayment and company profitability. The results of this study are not in accordance with the results of research Sharma \& Kumar (2011), stating that there is a negative relationship between the period of debt repayment and the profitability of the company.

\section{CONCLUSION}

Not always a low cash conversion cycle will result in high profitability. Research on the property \& real estate subsector shows different results. The results of the study stated that the debt repayment period has a positive influence on the return on assets of the company. The cash conversion cycle, inventory turnover period and collection period of accounts receivable, does not affect the return on assets of the company.

It can be concluded that the cash conversion cycle is not a determinant to increase profitability. Regression coefficients generated in the collection period of the receivables and debt repayment periods have a very weak influence. Working capital management in the cash conversion cycle has not been managed effectively and efficiently to create sales in generating profits for the company.

\section{Limitations}

This research still has many shortcomings so it needs improvement for further research. In this study there are several limitations, the first sample used in this study is only property \& real estate companies for the 2013-2016 period. Second, the data source used only comes from one source, namely the Indonesia Stock Exchange (IDX). Third, the proxy of the company's profitability is only measured using return on assets (ROA). Fourth, the control variables used in the study were only the size of the company and the age of the company. Judging from the low adjusted $R^{2}$ value on the coefficient of determination shows that the dependent variable can be explained by the independent variables and the control variables used in the study. The rest is explained by other variables outside the research model.

\section{Implications}

The implication in this study for companies is to give great attention to the management of accounts receivable and debt to get optimal profitability. Providing a long repayment period for consumers, can attract consumers to make purchases so as to increase the profitability of the company.

\section{Suggestions}

There are several suggestions for further research in order to obtain more optimal research results, including:

1. Expand the scope of research in the building construction sector so that the results of the study do not only have implications for the property \& real estate sector.

2. Adding proxy or measurement used for the dependent variable, for example return on investment (ROI), return on equity (ROE), gross operating profit (GOP), net profit margin (NPM).

3. Using control variables other than company size and age, for example leverage or debt asset ratio, current ratio and sales growth.

4. Add other measurement variables related to the management of company working capital such as the operating cycle and the net trade cycle.

5. Other working capital components such as gross working capital turnover ratio, current assets to total assets ratio, current liabilities to total assets ratio and current ratio are also components of 
working capital that can affect the efficiency and effectiveness of working capital management because it is related to current assets and current liability.

6. Increase research data by adding research period.

\section{REFERENCES}

Abuzayed, B. (2012). Working capital management and firms' performance in emerging markets: the case of Jordan. International Journal of Managerial Finance, Vol. 8, No. 2 , 155-179.

Alavinasab, S. M., \& Davoudi, E. (2013). Studying the Relationship between Working Capital Management and Profitability of Listed Companies in Tehran Stock Exchange. Business Management Dynamics, Vol. 2, No. 7 , 1-8.

Anser, R., \& Malik, Q. A. (2013). Cash Conversion Cycle and Firms' Profitability - A Study of Listed Manufacturing Companies of Pakistan . IOSR Journal of Business and Management, Vol. 8, No. 2 ,83-87.

Donaldson, T., \& Preston, L. E. (1995). The Stakeholder Theory of the Corporation: Concepts, Evidence, and Implications. The Academy of Management Review, Vol. 20, No. 1 , 65-91.

Freeman, R. E. (1994). The Politics of Stakeholder Theory: Some Future Directions. Business Ethics Quarterly, Vol.4, No.4, 409-421.

Ghozali, I. (2012). Aplikasi Analisis Multivariate dengan program IBM SPSS 20. Semarang: Universitas Diponegoro.

Gill, A., Biger, N., \& Mathur, N. (2010). The Relationship Between Working Capital Management And Profitability:Evidence From The United
States. Business and Economics Journal. Vol. 10, BEJ-10 , 1-9.

Gitman, L. J., \& Zutter, C. J. (2010). Principles of Managerial Finance 13th Edition. United State of America: Pearson Prentice Hall.

Isik, O. (2017). Determinants of Profitability: Evidence from Real Sector Firms Listed in Borsa Istanbul . Business and Economics Research Journal, Vol. 8, No. 4 , 689-698.

Jensen, M. C., \& Meckling, W. H. (1976). Theory of the firm: Managerial behavior, agency costs and ownership structure. Journal of Financial Economics, Vol. 3, No. 4, 305-360.

Keown, A. J., Martin, J. D., Petty, J. W., \& JR, D. F. (2008). Manajemen Keuangan. Edisi Kesepuluh, Jilid 1. Jakarta: PT. Indeks Kelompok Gramedia.

Malik, M. S., \& Bukhari, M. (2014). The Impact of Working Capital Management on Corporate Performance: A Study of Firms in Cement, Chemical and Engineering Sectors of Pakistan. Pakistan Journal of Commerce and Social Science , 134- 148.

Margaretha, F., \& Oktaviani, C. (2016). Pengaruh Manajemen Modal Kerja Terhadap Profitabilitas Pada Usaha Kecil Dan Menengah di Indonesia. Jurnal Bisnis Dan Akuntansi Vol. 18, No.1 , 11-24.

Muscettola, M. (2014). Cash Conversion Cycle and Firm's Profitability: An Empirical Analysis on a Sample of 4,226 Manufacturing SMEs of Italy. International Journal of Business and Management; Vol. 9, No. 5, 25-35.

Nur, H. B., Indrawati, N. K., \& Ratnawati, K. (2016). Pengaruh Manajemen Modal Kerja Terhadap Profitabilitas Perusahaan Non Keuangan Yang 
Terdaftar di Bursa Efek Indonesia.

Wacana. Vol. 19, No.2 , 82-91.

Ponsian, N., Chrispina, K., Tago, G., \& Mkiibi, H. (2014). The Effect of Working Capital Management on Profitability. International Journal of Economics, Finance and Management Sciences. Vol. 2, No. 6 , 347-355.

Ross, S. A. (1977). The Determination of Financial Structure: The IncentiveSignalling Approach. The Bell Journal of Economics, Vol. 8, No. 1, 23-40.

Yazdanfar, D., \& Ohman, P. (2014). The impact of cash conversion cycle on firm profitability : An empirical study based on Swedish data. International Journal of Managerial Finance Vol. 10 Iss. 4 , 442 - 452. 